\title{
Adoptive immunotherapy for AML with CD123-engager T cells
}

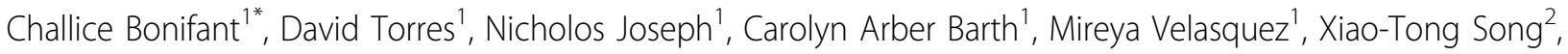 \\ Michele Redell', Stephen Gottschalk'
}

From 30th Annual Meeting and Associated Programs of the Society for Immunotherapy of Cancer (SITC 2015) National Harbor, MD, USA. 4-8 November 2015

\section{Background}

$\mathrm{T}$ cell immunotherapy is one promising approach to improve outcomes for patients with AML; however, infused $\mathrm{T}$ cells do not redirect resident $\mathrm{T}$ cells to tumors. To overcome this, we have genetically modified $\mathrm{T}$ cells to produce a secretable, bispecific $\mathrm{T}$ cell engager (ENG-T cells). Consistent synthesis of engagers by $\mathrm{T}$ cells should be superior to the direct infusion of the recombinant bispecific antibody, because bispecific proteins typically have short half-lives and do not accumulate at tumor sites. The goal of this project was to generate and characterize $\mathrm{T}$ cells expressing CD123-specific engagers and evaluate the feasibility of using transgenic expression of $\mathrm{CD} 20$ in combination with rituximab as a suicide gene.

\section{Methods}

CD123-ENG $\mathrm{T}$ cells were generated by transducing $\mathrm{T}$ cells with a retroviral vector encoding a CD123-specific $\mathrm{T}$ cell engager consisting of a scFv recognizing $\mathrm{CD} 123$ linked to a scFv recognizing CD3. The vector also contained mOrange or CD20 as a second transgene. Effector function of CD123-ENG $\mathrm{T}$ cells was evaluated in vitro and in a xenograft model. Toxicity of CD123-ENG $\mathrm{T}$ cells and the functionality of the suicide gene were evaluated in vitro and in vivo.

\section{Results}

Mean transduction efficiency was 76\% (49-95\%), and CD123-ENG and CD20.CD123-ENG T cells recognized CD123+ cells (MV-4-11, MOLM-1, KG1a, K562-CD123) as judged by cytokine production and cytolytic activity. CD123-negative cells (K562) were not recognized by

${ }^{1}$ Baylor College of Medicine, Center for Cell and Gene Therapy, Houston, TX, USA

Full list of author information is available at the end of the article
CD123-ENG T cells. Likewise, control ENG-T cells were not activated by CD123+ cells. Antigen-dependent recognition was confirmed with cytotoxicity assays. Since CD123 is expressed on normal hematopoietic progenitor cells (HPCs), we evaluated the ability of CD123-ENG $\mathrm{T}$ cells to recognize normal HPCs in colony formation assays. Only at high CD123-ENG to HPC ratios did we observe a decline in colony numbers. In contrast, toxicity to primary leukemia samples was apparent even at low CD123-ENG T cell:leukemia cell ratios, indicating that CD123+ AML cells can be targeted while preserving normal HPCs. In vivo, CD123-ENG T cells and CD20. CD123-ENG $T$ cells had potent anti-tumor activity in the KG1a/NSG xenograft model resulting in a significant survival advantage of treated animals in comparison to mice that received Control-ENG T cells $(\mathrm{p}=0.002)$. Lastly, CD20.CD123-ENG T cells were efficiently eliminated by rituximab in the presence of complement in contrast to CD123-ENG T cells.

\section{Conclusions}

We have generated CD123-ENG $\mathrm{T}$ cells that can direct bystander T cells to CD123+ AML in an antigen-specific manner. These CD123-ENG T cells have powerful antiAML activity in vivo and when further engineered to also express CD20, are eliminated by rituximab. These cells may present a promising addition to currently available AML therapies.

\section{Authors' details \\ ${ }^{1}$ Baylor College of Medicine, Center for Cell and Gene Therapy, Houston, TX, USA. ${ }^{2}$ Baylor College of Medicine, Houston, TX, USA.}

Published: 4 November 2015 
doi:10.1186/2051-1426-3-S2-P3

Cite this article as: Bonifant et al:: Adoptive immunotherapy for AML

with CD123-engager T cells. Journal for ImmunoTherapy of Cancer 20153

(Suppl 2):P3.

Submit your next manuscript to BioMed Central and take full advantage of:

- Convenient online submission

- Thorough peer review

- No space constraints or color figure charges

- Immediate publication on acceptance

- Inclusion in PubMed, CAS, Scopus and Google Scholar

- Research which is freely available for redistribution

Submit your manuscript at 